\section{Philip Melanchthon and the Cappadocians: $A$ Reception of Greek Patristic Sources in the Six- teenth Century, by H. Ashley Hall}

Refo500 Academic Studies I6 | Göttingen: Vandenhoeck und Ruprecht, 2014 | 272 pages | ISBN: 978-3-525-55067o (hardcover) €74.99 | ISBN: 978-3-647-55067-I (ebook) $€ 59.99$

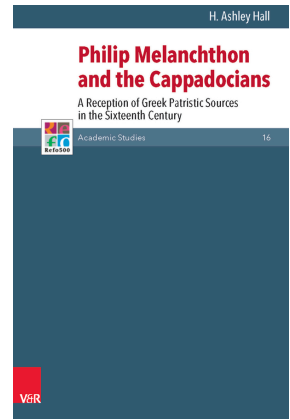

Hall's book begins with an introduction wherein our author identifies the Cappadocian Fathers who will make appearances in the pages which follow. Normally, the first thing that comes to mind when this reviewer sees the words "Church Fathers" is, "Oh no, I am about to be bored into a coma." Hall, however, has managed to work a miracle and make them interesting.

Chapter I is a well-designed and well-developed exposition of Melanchthon's understanding of Patristic authority. It also includes a subsection investigating key phrases and concepts utilized by the Cappadocians and made use of by Melanchthon. And it concludes with a discussion of the question which comes to mind as soon as one sees the subtitle of the volume: why the Cappadocians? In chapter 2, Hall describes Melanchthon's Sitz im Leben (for all intents and purposes) in relationship to the German university system of his time and its approach to the Fathers as well as his earliest lectures of the Cappadocian's theology.

Chapter 3 gives readers insight into the use to which Melanchthon put the Fathers in his struggles against the Radicals. Chapter 3, section 3.I is one of the several Himalayan peaks in a volume of mountainous excellence. There 
Hall takes in hand Melanchthon's oration on the importance of theological education. It is spectacular, absolutely timeless, and as necessary today as it was then. Chapter 4 addresses the same sort of subject as chapter 3, except this time it is not the Radicals who are the topic but the Romanists. Chapter 5 follows in the same track, this time in connection with the Reformed and the Lutheran opponents to whom Melanchthon was subjected and against whom he had to struggle his entire career. How the Cappadocians came to his rescue (he would have believed) is made evident in every subsection concerning every issue.

Those chapters, that is, 3-5 are really the heart of the study. How Melanchthon was able to call as witnesses in support of his views the Cappadocian Fathers in his many wars against Radicals, Reformed, and Romanists is the aim of Hall's monograph. For example, Hall observes,

In light of the Zwickau Prophets' rejection of formal theological education, the Wittenberg reformation was also shocked by a similar affirmation by one of its most learned faculty members: Andreas Karlstadt. ( I I o)

In response to Karlstadt, the Zwickauers, and the Anabaptist threat to Christian theology, Hall goes on to report,

Melanchthon's first work against the Anabaptists was Adversus anabaptistas iudicium (I 528). ... Melancthon's next anti-radical polemic was written in I 536, Verlegung etlicher unchristlicher Artikel welche die Widerteuffer fürgeben. (I IO-I I)

In these works, Melanchthon shows the historic position of Christianity, in opposition to the misrepresentations of theology by the radicals (of all stripes). Hall observes,

For Melanchthon, affirming the ancient creeds go hand in hand with a proper proclamation of the gospel. Thus, the Lutheran confessions are in harmony with the ancient church and-most importantly-they are so because they adhere to the ancient creeds. (I I 2-I3)

Throughout the book this is the methodology which Hall practices: the contemporary opponents of Melanchthon are described and their positions enunciated. Melanchthon's response is then offered and his use of the Church 
Fathers in that response highlighted, all in an attempt to show that Melanchthon's Lutheranism is in a continuous theological line descended from the primitive and therefore pure faith.

Another instance of Melanchthon's willingness to call the Fathers as witnesses can be found in Hall's discussion of Grace and Melanchthon's reliance on St. Basil:

The Basilian quotation cited more than any other by Melanchthon concerning grace is: only desire it and God has preceded. (207)

Throughout, then, what Hall shows is that Melanchthon desired not so much to be an innovator as a preserver of ancient tradition. His use of the Fathers in general and the Cappadocians, for whom he seems to have had a special regard, makes this, I think, quite clear.

The book ends with an appendix titled "The Reception of Cappadocian Texts in the Sixteenth Century" and the usual indices.

What I can say about this book is that it fills an important gap in our knowledge about Melanchthon's use of sources. It is, so far as I know, the first real in-depth treatment of this important topic. More of this kind of work is desirable for a number of reasons. First, it helps us understand the Reformer's methodology in actual practice and not merely as theoretical abstractions. Second, it sheds light on the interaction between Reformers and interlocutors beyond their use of the biblical text. That is, normally when we discuss the Reformers we discuss their use of the Bible. This study, on the other hand, allows readers to get important insights into the ways that Reformers understood texts beyond the Bible.

It seems to this reviewer, then, that this volume is an important first step in a new direction of historical research: the use to which Reformers put extra-biblical texts, in monograph-length treatments.

$\mathrm{H}$. Ashley Hall is to be commended for this volume. I recommend that persons interested in Melanchthon's works obtain a copy and work carefully through it. It is both engrossing and gratifying. Furthermore, persons interested in reception history too will benefit from the volume, as its method is quite sensible and intelligent. 